\title{
Biomechanics of footwear design
}

\author{
Richard Smith*, Caleb Wegener, Andy Greene, Angus Chard, Alycia Fong Yan \\ From 3rd Congress of the International Foot and Ankle Biomechanics Community \\ Sydney, Australia. 11-13 April 2012
}

\section{Background}

The aim of the workshop is to explore the effects of footwear design on lower limb motion and discuss research findings relevant to the clinic and physical activity. Delegates will be actively involved in a motion capture process where important lower limb joint stress variables will be displayed in real time. The University of Sydney researchers will raise footwear issues from a range of areas such as children physical activity, adult walking and running, specific footwear such as thongs (flip-flops), dance and experimental methodology.

During or on completion of this workshop, participants will be able to:

- Critically analyse footwear characteristics that are likely to influence lower limb function during physical activity.

- Experience the use of state of the art technology to analyse lower limb mechanics.

- Discuss the models and methods used to build knowledge about the effect of footwear on lower limb mechanics.

- Recount clinical and research outcomes for the effect of footwear on lower limb biomechanics during physical activity.

- Apply biomechanical principles to the effective choice of footwear for a range of physical activities.

Submit your next manuscript to BioMed Central and take full advantage of:

- Convenient online submission

- Thorough peer review

- No space constraints or color figure charges

- Immediate publication on acceptance

- Inclusion in PubMed, CAS, Scopus and Google Scholar

- Research which is freely available for redistribution 